\title{
Consumers' Purchase Intention Toward Ergonomic Footwear in Malaysia
}

\author{
Shyue Chuan Chong ${ }^{1}$, Foong Yee $\operatorname{Tan}^{1}$, Pei Yew Mah ${ }^{1} \&$ Choon Wei Low ${ }^{1}$ \\ ${ }^{1}$ Universiti Tunku Abdul Rahman, Malaysia \\ Correspondence: Shyue Chuan Chong, Faculty of Accountancy and Management, Universiti Tunku Abdul Rahman, \\ Malaysia.
}

Received: October 15, 2019

Accepted: December 19, 2019

Online Published: March 16, 2020

doi:10.5430/ijfr.v11n2p88

URL: https://doi.org/10.5430/ijfr.v11n2p88

\begin{abstract}
Ergonomic footwear is a type of shoe specifically designed for consumers to treat foot problems. In accelerating concern on foot health nowadays, ergonomic footwear is introduced to fill the gap in the context of Malaysia. This study applied the Theory of Planned Behaviour and Expectancy-Value Theory to explore the consumers' purchase intention toward ergonomic footwear. Targeted respondents were adults in Klang Valley, Malaysia aged from 21 years and above through judgmental sampling. A total of 221 responses were collected using a survey questionnaire from June to July 2018. This study found that utilitarian consumption, consumer perceived value and perceived trust have a significant positive relationship with the purchase intention. Meanwhile, the word-of-mouth shows the insignificant relationship between purchase intention. Word-of-mouth is unimportant might be due to contrary word-of-mouth spread by experienced customers, and perhaps the less tendency the consumers rely on word-of-mouth.
\end{abstract}

Keywords: theory of planned behavior, expectancy-value theory, ergonomic footwear, utilitarian consumption, consumer' perceived value, perceived trust, purchased intention

\section{Introduction}

Footwear is a necessity for every human; it serves more than just protection and comfort apparel. It also indicates the status and fashion of an individual; importantly, they will concern the choice of shoes when it jeopardizes their health. The issue of ergonomic footwear is essential nowadays, in which it is specifically designed to treat foot problems. Ergonomic shoes, also known as orthopaedic shoes, in which people associate orthopaedic shoes with diabetic patients and older adults who suffered from foot problems (APMA, 2014). In the current trend, ergonomic footwear has reformed as usual shoes worn by people of all ages. Comparatively, with regular footwear, the customer needs to undergo a biomechanical assessment before selecting ergonomic footwear by a qualified podiatrist. Foot test will be conducted to examine customers' lower limbs and foot conditions, meanwhile, the result of foot diagnosis acts as a guideline for customers in choosing suitable ergonomic footwear (Lim, 2017).

According to the survey conducted by the American Podiatric Medical Association (APMA, 2014), about 80\% of adults are having foot pain. However, only $30 \%$ of them seek for expert care treatment. Specifically, $88 \%$ suffer mild to severe foot pronation and supination from the population in Malaysia, while $90 \%$ suffer from leg length inequality. Thus, customers opt for choosing ergonomic footwear in the current market trend. Footwear industry in Malaysia is the country's oldest manufacturing, yield approximately 70 million pairs annually (Ruixia \& Chein, 2019). Importantly, Malaysia is the $13^{\text {th }}$ largest key player in Asia's footwear industry (Italian Trade Agency 2012; MATRADE, 2015) According to MATRADE, footwear business has huge growth potential for the market by increasing the awareness of footwear through designing comfortable and innovative shoes (New Straits Times, 2017). In the clothing and footwear industry, Malaysians contributed 3.4\% in 2016 (DOSM, 2017) However, sales value for textile, wearing apparel, leather and footwear in the third quarter of 2018 is $4.7 \%$ and $3.2 \%$ in the next quarter of 2018. It showed a decline of $1.2 \%$ in the fourth quarter of 2018 . The issue arises when the sales in the footwear market in Malaysia decreases in 2018 (DOSM, 2019). In order to increase sales in the footwear industry, it is essential to determine the factors that lead to customers' purchase intention towards ergonomic footwear in Malaysia. 
Additionally, previous clinical studies reveal that the foot issue has a connection with diabetic (Arts et al., 2014) and rheumatoid arthritis patients (Stolt, Suhonen \& Leino-Kilpi, 2017). Past studies showed a positive relationship between consumer perceived value, perceived trust and purchase intention in the healthcare industry. However, variables on foot health products are limited. Additionally, customers rely on word-of-mouth in purchasing health products, but the level of consciousness towards foot health is relatively low in Malaysia. However, not many studies focus on foot issues among non-diabetic population and perception towards ergonomic footwear in Malaysia. Therefore, it is essential to determine the factors affecting consumers' perception and their purchase intention towards ergonomic footwear in Malaysia.

The purpose of this study is to analyze the relationship between utilitarian consumption, consumer perceived value, word-of-mouth communication and consumer purchase intention towards ergonomic footwear among non-diabetic consumers in Malaysia. This study contributes new knowledge on consumer behaviour in ergonomic footwear towards the non-diabetic consumer in Malaysia. It provides insights for policymakers to strategize their actions towards increasing the level of consumption in ergonomic footwear.

\section{Literature Review}

Theory of Planned Behavior refers to goal-oriented and well-formulated intention to conform to individual action (Ajzen, 1985). Expectancy-Value Theory was employed in this study, which refers to an individual with stronger intention in achieving a specific outcome; they highly react within a controllable situation (Ajzen, 1991). This research using both theories for investigating human behavior and decision-making process on health and safety-related behavior. In this study, customers purchase intention towards ergonomic footwear is linked with pleasant quality, value, trust and words from customer evangelists who spread about their good experiences and thus, link with customer's behavior and action. Customer purchase intention is formed through the advertisement of a certain brand of products (Ahmad, Idris, Mason \& Chow, 2019). Purchase intention comprises repurchase intention. Similarly, the theory of planned behaviour is highly associated with purchase intention (Ajzen, 1991; Jing et al., 2019; Lim \& Goh, 2019; Salem \& Salem, 2018; Wang, et al., 2018; Zhang et al., 2018). Repurchase behaviour occurs after customers receiving experiential benefits from the same resellers (Patterson \& Spreng, 1997; Nieto, Hernandez-Maestro \& Munoz-Gallego, 2014). Conclusively, none of all purchase intentions will lead to a successful buying process (Ladhari, Souiden \& Dufour, 2017).

Moreover, customer purchase intention towards product categories is varied; they tend to have higher purchase intention for existing products compare with new products (Lim, 2017). Also, another form of purchase intention is information adoption, in which customer purchases based on messages conveyed by salespersons and word-of-mouth (Baker, Donthu \& Kumar, 2016). Utilitarian refers to an action which motivates an individual to fulfil their basic need or actual needs (Chang, Chen \& Lan, 2013). Customer possesses positive utilitarian responses towards receiving pleasant quality service (Ladhari, Souiden \& Dufour, 2017). Consumer reacts differently with different product categories in high-low utilitarian dimensions (Voss, Spangenberg \& Grohmann, 2003). Consumer perceived value is the perception by the consumer on the level of worthiness towards what is received and what is given (Zeithaml, 1998). It is also referred to as the relationship between benefits received and the price paid, in which higher price indicates higher quality received (Imkamp, 2018). Word-of-mouth is the act of transferring information from one party to another. It becomes a source of reference for the new user, and the information is initiated based on consumer experience (Nieto, Hernandez-Maestro \& Munoz-Gallego, 2014). Particularly in the healthcare industry, word-of-mouth used as a source of useful information in a pre-purchase buying decision. Perceived trust occurs between trustor and trustee towards the willingness to count on trustee action. Likewise, it refers to the level of trust by trustor based on the action of "give and take", if the trustee did not deliver as promised. Perceived trust is associated with perceived service quality (Thom, Hall \& Pawlson, 2004). It represents how the service delivered has meet consumer's expectations (Parasuraman, Berry \& Zeithaml, 1991). The presence of communication between employees and customers will lead to overall perceived quality as well as the increase of perceived trust. The proposed research framework of this study is shown in Figure 1. 


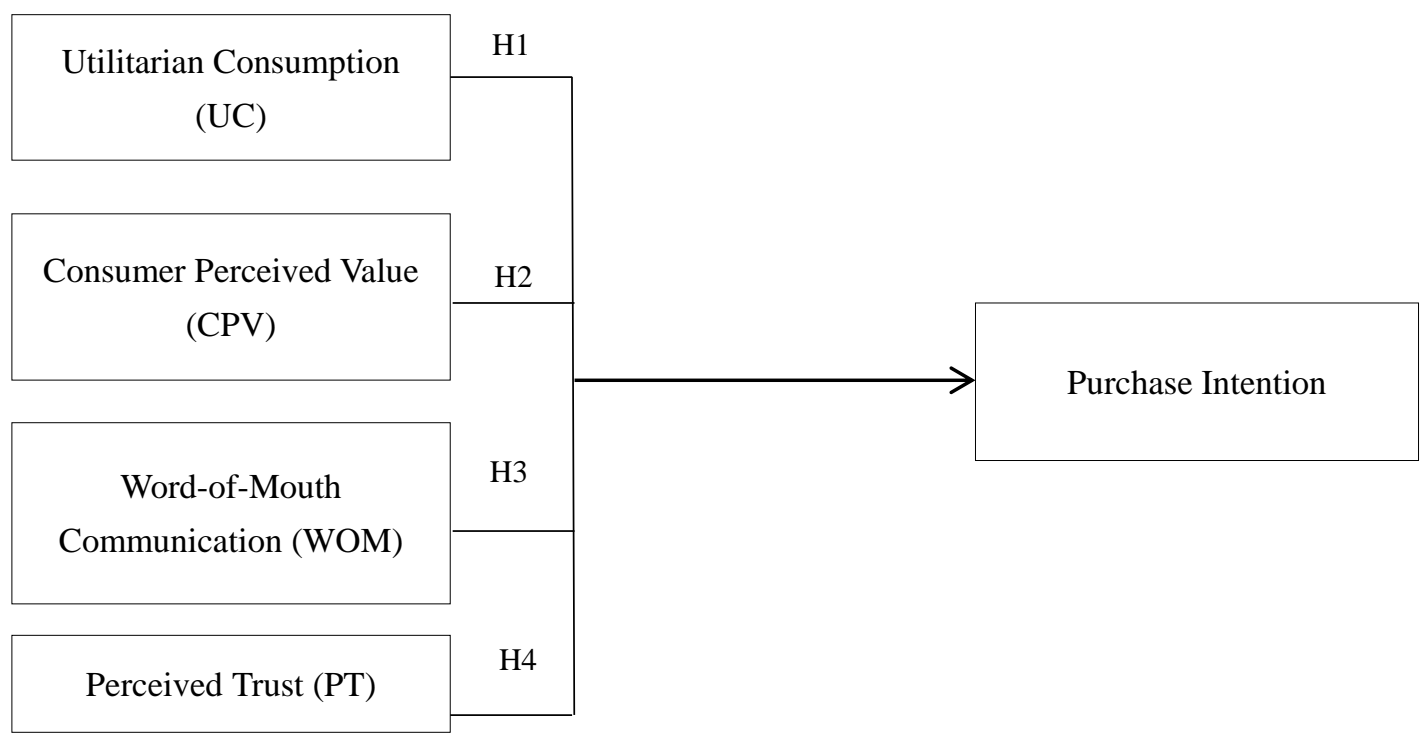

Figure 1. Consumer perception and purchase intention of ergonomic footwear in Malaysia

\subsection{Hypothesis Development}

Based on the previous studies, the hypotheses in this study were developed. The dependent variable is the consumer purchase intention towards ergonomic footwear, while the independent variables are utilitarian consumption, consumer perceived value, word-of-mouth communication and perceived trust. Customer expectation in receiving intensive foot care and treating footwear bring symbolic valences to the wearers will directly lead to purchase intention towards ergonomic footwear. Based on past evidence, utilitarian consumption is an important component of purchase intention towards health-related products (Vieira, Santini \& Araujo, 2018). Thus, the following hypothesis between consumer purchase intention and utilitarian consumption is developed.

H1: Utilitarian consumption has a positive relationship between purchase intention in ergonomic footwear.

Ergonomic footwear is closely related to medical treatment; a different level of foot pain provides a different level of outcome in customer perceived value. From the perspective of the retail environment, specifically in the footwear industry, perceived value showed a great impact on consumer purchase intention. The need for getting feet healed is linked with customer purchase value. Consumer purchase value is an important element for consumer purchase intention in the health-related product (Roudposhti et al., 2018; Yu \& Lee, 2019; Sweeney \& Soutar, 2001). Thus, the following hypothesis between consumer purchase intention and consumer purchase intention is developed.

$\mathrm{H} 2$ : Consumer purchase value has a positive relationship between purchase intention in ergonomic footwear.

The combination of podiatry service and biomechanical engineering concepts in ergonomic footwear is to meet customer's demand in shoe-wearing experience. The need for word-of-mouth in providing recommendations is an essential, specialized health industry. Word-of-mouth in the pre-purchase scenario is associated with consumer purchase intention (Baker, Donthu \& Kumar, 2016; Nieto, Hernandez-Maestro \& Munoz-Gallego, 2014). Particularly, it provides information search on the practice and functionality of unknown products to the customers. Generally, the quality and content of a word will lead to purchase intention. Word-of-mouth communication is an important element to purchase intention of the health-related product. Thus, the following hypothesis between consumer purchase intention and word-of-mouth communication is developed.

H3: Word-of-mouth communication has a positive relationship between purchase intention in ergonomic footwear.

The trait of service quality derived from the act of operating and providing advice on treatment is a component of building trust. By providing personal engagement, the customer has a higher purchase intention to purchase. Previous studies proved that perceived service quality influenced consumer perception towards a brand, while perceived trust moving towards business and triggered purchase intention (Rachbini, 2018; Thom, Hall \& Pawlson, 2004). Similarly, perceived trust is linked to a customer's perception of a brand and service quality before making a 
purchase decision. Thus, the following hypothesis between consumer purchase intention and purchase trust is developed.

H4: Perceived trust has a positive relationship between purchase intention in ergonomic footwear.

\section{Methodology}

The respondent from this study focused on urban adults in Malaysia. It is applied to urban adult consumers who have interest in ergonomic footwear aged 21 years and above. This study employed the non-probability sampling method. Particularly, this study used judgmental sampling technique to get responses from Malaysian consumers from Klang Valley. Respondents are presumed to have knowledge about foot problems, attended health talk and interested in ergonomic footwear. Their ability to understand and purchasing elements are vital to ensure data obtained accurately in this study. The data was analyzed using Partial Least Squares (PLS). A total of 221 responses were collected using a survey questionnaire from June to July 2018. This study primarily used a quantitative approach, in which the main purpose was to investigate the relationship between utilitarian consumption, customer perceived value, word-of-mouth communication, perceived trust and customers' purchase intention towards ergonomic footwear. The questionnaire adopted a five-point Likert scale ranging from 1 ("strongly disagree") to 5 ("strongly agree") in all the measurements and was distributed to the respondents. The questionnaire was divided into two sections. Section A includes questions measuring the demographic profile of respondents, meanwhile Section B measuring customers' perception of the chosen ergonomic footwear.

\section{Findings}

This study conducted a Confirmatory Factor Analysis (CFA) to validate the measurement model and to examine the relationship between dependent and independent variables. Reflective measurement was used in this study. The measurement model indicated the validity and reliability of all items, as shown in Figure 2. The outer loadings represent the indicator reliability, composite reliability and Cronbach's alpha represents internal consistency reliability, Average Value Extracted (AVE) represents convergent validity and discriminant validity represents the items measuring different concepts, in which the indicator must be greater than cross-loading on the other construct as in Fornell-Larcker criterion (Hair et al., 2017). Table 1 indicates the characteristics of respondents in descriptive analysis.

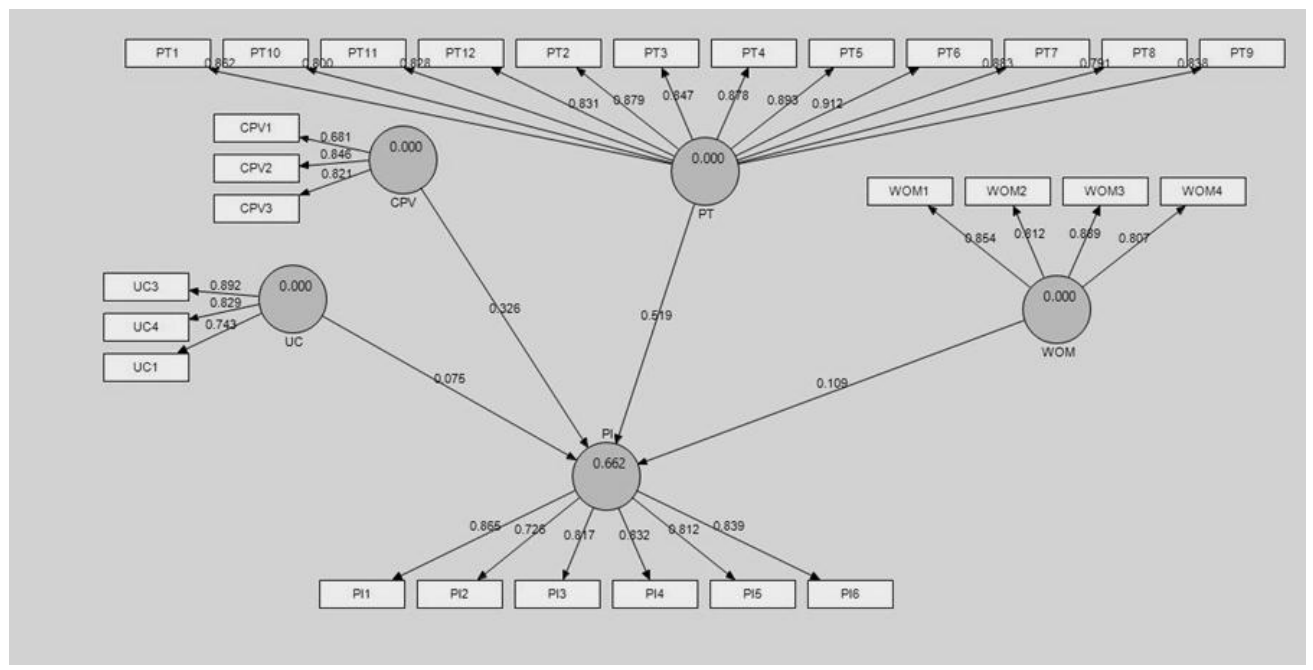

Figure 2. Measurement model

Factor loadings for all items met the specification of the recommended value of above 0.5 (Hair et al., 2010), the value for Cronbach's alpha and composite reliability was above 0.6 and 0.7 , respectively (Chong, 2014). Reliability scores for all the constructs were above 0.6 ; it shows consistency in measuring the construct for overall reliability. 
Table 1. Ethnicity, gender, age, education and employment status of respondents

\begin{tabular}{llll}
\hline Characteristics & \% & Characteristics & M \\
\hline Age & & Monthly Household Expenses & \\
\hline 21 to 40 & 62.0 & Below RM4,000 & 53.4 \\
\hline 41 and above & 38.0 & RM4,000 - 7,999 & 28.0 \\
\hline & & RM8,000 and above & 18.6 \\
\hline Educational Level & & Employment status & 41.2 \\
\hline No formal education, primary and secondary & 10.9 & Private sector & 29.0 \\
\hline Pre-U, STPM, A-Level, certificate and diploma & 21.7 & Public sector & 15.3 \\
\hline Degree and professional qualification & 54.3 & Employer and self-employed & 14.4 \\
\hline Master and PhD & 13.1 & Others & $\mathbf{1 0 0 . 0}$ \\
\hline Total & $\mathbf{1 0 0 . 0}$ & Total & $\mathbf{( 2 2 1 )}$ \\
\hline Sample size (n) & $\mathbf{( 2 2 1 )}$ & Sample size (n) &
\end{tabular}

Table 2. Internal consistency and convergent validity

\begin{tabular}{lllll}
\hline Constructs & Loadings & AVE & CR & Cronbach's $\alpha$ \\
\hline Customer Purchase Value (CPV) & & 0.6179 & 0.8279 & 0.6938 \\
\hline CPV1: This item would be approved of by others. & 0.6809 & & & \\
\hline CPV2: This item has a positive social image. & 0.8465 & & & \\
\hline $\begin{array}{l}\text { CPV3: If I bought or used this item, it would create a } \\
\text { favourable perception of me among other people }\end{array}$ & 0.8206 & & & \\
\hline Purchase Intention (PI) & & 0.6662 & 0.9227 & 0.8993 \\
\hline $\begin{array}{l}\text { PI1: I would purchase ergonomic footwear. } \\
\text { P12: I would consider buying at this price. }\end{array}$ & 0.8646 & & & \\
\hline $\begin{array}{l}\text { PI3: The probability that I would consider buying is } \\
\text { high. }\end{array}$ & 0.8166 & & & \\
\hline $\begin{array}{l}\text { PI4: This footwear brand possesses complete practical } \\
\text { functions (ease the foot pain) }\end{array}$ & 0.8320 & & & \\
\hline $\begin{array}{l}\text { PI5: For me, this footwear brand is reputable, credible, } \\
\text { and possesses a positive image. }\end{array}$ & 0.8123 & & & \\
\hline $\begin{array}{l}\text { PI6: For me, this footwear brand can offer me comfort } \\
\text { wearing experience. }\end{array}$ & 0.8390 & & & \\
\hline Perceived Trust (PT) & & & & \\
\hline $\begin{array}{l}\text { PT1: The employees have provided the personal } \\
\text { attention I need from them. }\end{array}$ & & & & \\
\hline $\begin{array}{l}\text { PT2: The behaviour of employees have instilled in me } \\
\text { the confidence }\end{array}$ & 0.8789 & & \\
\hline $\begin{array}{l}\text { PT3: The employees are courteous. } \\
\text { PT4: I have received sufficient individual attention from }\end{array}$ & 0.8783 & & \\
the employees. & & & & \\
\hline
\end{tabular}


PT5: I have received prompt service from the employees 0.8935

PT6: I feel safe in dealing with the employees. 0.9124

PT7: The employees can answer my questions and clear 0.8830 my doubts.

PT8: The employees are responsive to my requests. $\quad 0.7913$

PT9: The employees will honestly inform me about the 0.8377

result of the diagnosis.

PT10: The employees well handle my foot issues. 0.7999

PT11: I can trust the employee's judgement based on my 0.8277 foot issues.

PT12: I can rely on the employees to solve my foot 0.8312 issues

\begin{tabular}{|c|c|c|c|c|}
\hline Utilitarian Consumption (UC) & & 0.6779 & 0.8626 & 0.7587 \\
\hline $\begin{array}{l}\text { UC1: Normally, I accomplish what I wanted to on the } \\
\text { shopping trip. }\end{array}$ & 0.7430 & & & \\
\hline $\begin{array}{l}\text { UC2: While shopping, I find just the item(s) I was } \\
\text { looking for. }\end{array}$ & Dropped & & & \\
\hline UC3: I feel my shopping trip is successful. & 0.8917 & & & \\
\hline UC4: I feel really smart about my shopping trip. & 0.8285 & & & \\
\hline Word of Mouth (WOM) & & 0.7076 & 0.9062 & 0.8618 \\
\hline $\begin{array}{l}\text { WOM1: My family and friends would influence my } \\
\text { attitude towards this brand. }\end{array}$ & 0.8535 & & & \\
\hline $\begin{array}{l}\text { WOM2: My family and friends would give different } \\
\text { ideas about this brand. }\end{array}$ & 0.8122 & & & \\
\hline $\begin{array}{l}\text { WOM3: My family and friends would influence my } \\
\text { evaluation of this brand. }\end{array}$ & 0.8890 & & & \\
\hline $\begin{array}{l}\text { WOM4: My family and friends would decide for me in } \\
\text { selecting this brand. }\end{array}$ & 0.8074 & & & \\
\hline
\end{tabular}

Table 3 represents the discriminant validity of each different concept. Firstly, the value of the indicator must be greater than the cross-loading on other constructs and secondly; the value of square root AVE must be greater than all other variables (Hair et al., 2017). The structural model was tested in this study to measure the relationship between each construct. The benchmark for the significant level at 5\% indicates that the t-value must be greater than 1.45. Results of the measurement model are satisfactory, and it is appropriate to further with the evaluation of the structural model.

Table 3. Discriminant validity

\begin{tabular}{llllll}
\hline Constructs & CPV & PI & PT & UC & WOM \\
\hline CPV & $\mathbf{0 . 7 8 6 0}$ & & & & \\
\hline PI & 0.6249 & $\mathbf{0 . 8 1 6 2}$ & & & \\
\hline PT & 0.4540 & 0.7358 & $\mathbf{0 . 8 5 4 3}$ & & \\
\hline UC & 0.2688 & 0.3823 & 0.3853 & $\mathbf{0 . 8 2 3 3}$ & 0.1813 \\
\hline WOM & 0.3988 & 0.4434 & 0.3682 & $\mathbf{0 . 8 4 1 2}$ \\
\hline
\end{tabular}


Table 4. Structural model: path coefficient analysis

\begin{tabular}{lllll}
\hline Hypothesis & Relationships & Standard Beta & t-value & Decision \\
\hline H1 & UC vs PI & 0.3257 & 6.0172 & Supported* \\
\hline H2 & CPV vs PI & 0.5190 & 9.8028 & Supported* \\
\hline H3 & WOM vs PI & 0.0750 & 1.4620 & Not supported \\
\hline H4 & PT vs PI & 0.1088 & 2.1210 & Supported* \\
\hline
\end{tabular}

* Significant at $5 \%$ level

Table 4 represents the results of the structural model. H1 is supported to indicate a significant positive relationship between utilitarian consumption and purchase intention at a 5\% level. This result is in line with [Vieira, Santini \& Araujo, 2018]. Customer perceived value also exhibited a significant positive relationship on purchase intention at a $5 \%$ level. Also, $\mathrm{H} 2$ was found supported. The finding was in accord with previous studies (Roudposhti et al., 2018; Sweeney \& Soutar, 2001). H4 is supported, perceived trust has a significant positive relationship on purchase intention at a 5\% level and in line with previous studies (Thom, Hall \& Pawlson, 2004; Brady et al., 2005; Chang, Chen \& Lan, 2013). However, H3 is not supported. Word-of-mouth has an insignificant positive relationship between purchase intention. This is due to negative word-of-mouth provided by experienced customers and actively spreading negative feedback towards the products. It will directly decrease the level of purchase intention and they tend to re-evaluate the searched alternatives towards ergonomic footwear. It shows different results conducted by (O'Cass \& Grace, 2004). Thus, H1, H2, and H4 were found supported in this study.

\section{Discussion and Conclusion}

In theoretical implication, this study utilized the Theory of Planned Behaviour and Expectancy-Value Theory to understand the perception of consumers towards purchase intention. The result shows that utilitarian consumption, consumer perceived value and perceived trust had a significant relationship between purchase intention in ergonomic footwear. It can be concluded that utilitarian consumption customers are more practical-type as they would seek for suitability of their footwear based on their comfort footwear experiences. Customers with higher perceived health benefits in utilitarian consumption, the higher their purchase intention towards ergonomic footwear. As for perceived value, customers are expected to receive health benefits as much as the cost incurred. Thus, the greater the expected health benefits received from ergonomic footwear, the greater the intention to purchase. Purchasing ergonomic footwear relies heavily on trust as this type of footwear improves consumer's health. It can be concluded that the ability of ergonomic footwear demonstrates good health products will increase customers' trust and directly increase the likelihood of purchase intention towards the products.

However, word-of-mouth has an insignificant impact on consumer purchase intention in ergonomic footwear. Experienced customers actively propagate negative feedback will lead to a decrease in trust towards the products. In managerial implication, consumers are concern about wearing comfort shoe experience; it indicates that their health benefits act as utilitarian values in their shopping behaviour. Additionally, consumers depend heavily on the value of the product or service rather than the displayed price tags; they are more focusing on their health benefits over the cost. Ergonomic footwear directly linked to health product with a high tendency of trust occurs among consumers and thus lead to purchase intention. Word-of-mouth is insignificant may be due to the negative word-of-mouth spread by experienced customers, and perhaps the less tendency the consumers rely on word-of-mouth.

There are some limitations to this study. The study was limited to adults staying in Klang Valley, aged 21 years and above. The location may not represent the entire view of the nation towards consumer perception and purchase intention of ergonomic footwear, as the different customer might have a different perspective towards ergonomic footwear. Thus, it is good to extend the research in different locations across Malaysia as it represents consumer perception in different states and areas. As compared with a single location, the result reflects the current situation and demonstrates a more accurate result.

In this study, it is found that utilitarian consumption, consumer perceived value and perceived trust were found significant. It is believed that there are other determinants would lead to a better understanding of ergonomic footwear. Thus, researchers may explore other underlying factors that influence customer purchase intention of ergonomic footwear. To sum up, foot care education is essential to improve public awareness on foot health, which in turn fosters a productive and healthier life. Particularly, individuals who involved in the healthcare industry and 
healthcare practitioners such as podiatrists, pharmacists, physiotherapists should contribute to educating people, parallelly spreading awareness on foot health.

\section{References}

Ahmad, A., Idris, I., Mason, C., \& Chow, S. K. (2019). The impact of young celebrity endorsements in social media advertisement and brand image towards the purchase intention of young consumers. International Journal of Financial Research, 10(5), 54-65. https://doi.org/10.5430/ijfr.v10n5p54

Ajzen, I. (1985). From intentions to actions: A theory of planned behavior. In Action control (pp. 11-39). Springer Berlin Heidelberg. http://doi 10.1007/978-3-642-69746-3_2

Ajzen, I. (1991). The theory of planned behavior. Organizational Behavior and Human Decision Processes, 50(2), 179-211. https://doi.org/10.1016/0749-5978(91)90020-T

APMA. (2014, March). Public Opinion Research on Foot Health and Care: Findings from a Survey of 1000 US Adults. American Podiatric Medical Association. Retrieved from https://www.apma.org/files/APMA2014TodaysPodiatristSurveyAllFindingspdf

Arts, M, L., de Haart, M., Bus, S. A., Bakker, J. P., Hacking, H. G., \& Nollet, F. (2014). Perceived usability and use of custom-made footwear in diabetic patients at high risk for foot ulceration. Journal of Rehabilitation Medicine, 46(4), 357-362. https://doi.org/10.2340/16501977-1272

Baker, A. M., Donthu, N., \& Kumar, V. (2016). Investigating how word-of-mouth conversations about brands influence purchase and retransmission intentions. Journal of Marketing Research, 53(2), 225-239. https://doi.org/10.1509/jmr.14.0099

Brady, M. K., Knight, G. A., Cronin, J. J. Jr., Tomas, G., Hult, M., \& Keillor, B. D. (2005). Removing the contextual lens: A multinational, multi-setting comparison of service evaluation models. Journal of Retailing, 81(3), 215-230. https://doi.org/10.1016/j.jretai.2005.07.005

Chang, C. S., Chen, S. Y., \& Lan, Y. T. (2013). Service quality, trust, and patient satisfaction in interpersonal-based medical service encounters. BMC Health Services Research, 13(1), 22. Retrieved from https://bmchealthservres.biomedcentral.com/articles/10.1186/1472-6963-13-22

Chong, S. C., Lim, C. S., \& Sia, B. K. (2014). Bequest Perceptions Among Malaysia's Urban Older Adults. Australian Journal of Basic and Applied Sciences, 8(5), 23-34.

DOSM. (2017). Report on household expenditure survey 2016. Retrieved from https://www.dosm.gov.my/v1/index.php?r=column/pdfPrev\&id=WnZvZWNVexzJjZ3RIUVVYU2s2Zz09

DOSM. (2018). Report on sales value survey 2018. Retrieved from https://www.dosm.gov.my/v1/uploads/files/7_Publication/Infographic/PocketStats/Pocket_Stats_Q4 2018.pdf

Hair, J. F. J., Black, W. C., Babin, B. J., Anderson, R. E., \& Tatham, R. L. (2010). Multivariate Data Analysis a Global Perspective. New Jersey: Pearson Education International.

Hair, J. F., Hult, G. T. M., Ringle, C. M., \& Sarstedt, M. (2017) A Primer on Partial Least Squares Structural Equation Modeling (PLS-SEM) (2nd ed.). USA: Sage Publication, Inc.

Imkamp, H. (2018). Should Prices of Consumer Goods Be Better Indicators Product Quality?. Journal of Consumer Policy, 41(1), 77-81. https://doi.org/10.1007/s10603-0189367-2

Italian Trade Agency. (2012). An overview on Malaysian footwear industry. Via Liszt, Rome, Italy.

Jing, P., Huang, H., Ran, B., Zhan, F., \& Shi. Y. (2019). Exploring the Factors Affecting Mode Choice Intention of Autonomous Vehicle Based on an Extended Theory of Planned Behavior - A Case Study in China. Sustainability, 11(4), 1155. https://doi.org/10.3390/su11041155

Ladhari, R., Souiden, N., \& Dufour, B. (2017). The role of emotions in utilitarian service settings: The effects of emotional satisfaction on product perception and behavioral intentions. Journal of Retailing and Consumer Services, 34, 10-18. https://doi.org/10.1016/j.jretconser.2016.09.005

Lim, C. C., \& Goh, Y. N. (2019). Investigating the Purchase Intention Towards Healthy Drinks among Urban Consumers in Malaysia. Journal of Food Service Business Research, 22(3), 286-302. https://doi.org/10.1080/15378020.2019.1603043 
Lim, J. (2017, August 18). Both feet firmly in the market. Retrieved from https://www.thestar.com.my/metro/smebiz/news/2017/08/18/both-feetfirmlyin-themarket-orthoticsspecialist-sha res-how-changing-to-a-retailconcept-hashelp/

New Straits Times. (2017). Matrade: Go into Footwear Business. Retrieved from https://www.pressreader.com/malaysia/new-straits-times/20171021/282295320440669

Nieto, J., Hernandez-Maestro, R. M., \& Munoz-Gallego, P. A. (2014). Marketing decision customer reviews, and business performance: The use of the Toprural website by Spanish rural lodging establishments. Tourism Management, 45, 115-123. https://doi.org/10.1016/j.tourman.2014.03.009

O" Cass, A., \& Grace, D. (2004). Exploring consumer experiences with a service brand. Journal of Product \& Brand Management, 13(4), 257-268. https://doi.org/10.1108/10610420410546961

Parasuraman, A., Berry, L. L., \& Zeithaml, V. A. (1991). Understanding customer expectations of service. Sloan Management Review, 32(3), 39-48.

Patterson, P. G., \& Spreng, R. A. (1997). Modelling the relationship between perceived value, satisfaction and repurchase intentions in a business-to-business, services context: An empirical examination. International Journal of Service Industry Management, 8(5), 414-434. https://doi.org/10.1108/09564239710189835

Rachbini, W. (2018). The Impact of Consumer Trust, Perceived Risk, Perceived Benefit on Purchase Intention and Purchase Decision. International Journal of Advanced Research, 6(1), 1036-1044.

Roudposhti, V. M., Nilashi, M., Mardani, A., Streimikiene, D., Samad, S., \& Ibrahim, O.(2018). A model for customer purchase intention in e-commerce recommendation agents. Journal of International Studies, 11(4), 237-253. https://doi.org/10.14254/2071-8330.2018/11-4/17

Ruixia, L., \& Chein, T. S. (2019). Analysing the Moderating Effects of Generational Cohorts on Brand Loyalty in the Malaysian Footwear Industry. Jurnal Pengurusan (UKM Journal of Management), 56.

Salem, S. F., \& Salem, S. O. (2018). Self-identity and Social Identity as Drivers of Consumers' Purchase Intention Towards Luxury Fashion Goods and Willingness to Pay Premium Price. Asian Academy of Management Journal, 23(2), 161-184. https://doi.org/10.21315/aamj2018.23.2.8

Stolt, M., Suhonen, R., \& Leino-Kilpi, H. (2017). Foot health in patients with rheumatoid arthritis. A Scoping Review Rheumatology International, 37(9), 1413-1422. https://doi.org/10.1007/s00296-017-3699-0

Sweeney, J. C., \& Soutar, G. N. (2001). Consumer perceived value: The development of a multiple item scale. Journal of Retailing, 77(2), 203-220. https://doi.org/10.1016/S00224359(01)00041-0

Thom, D. H., Hall, M. A., \& Pawlson, L. G. (2004). Measuring patients trust in physicians when assessing quality of care. Health Affairs, 23(4), 124-132. https://doi.org/10.1377/hlthaff.23.4.124

Vieira, V., Santini, F. O., \& Araujo, C. F. (2018). A meta-analytic review of hedonic and utilitarian shopping values. Journal of Consumer Marketing, 35(4), 426-437. https://doi.org/10.1108/JCM-08-2016-1914

Voss, K. E., Spangenberg, E. R., \& Grohmann, B. (2003). Measuring the hedonic and utilitarian dimensions of consumer attitude. Journal of Marketing Research, 40(3), 310-320. https://doi.org/10.1509/jmkr.40.3.310.19238

Wang, L., Wong, P. P. W., Alagas, E. N., \& Chee, W. M. (2018). Green Hotel Selection of Chinese Consumers: A Planned Behavior Perspective. Journal of China Tourism Research, 15(2), 192-212. https://doi.org/10.1080/19388160.2018.1553743

Yu, S., \& Lee, J. (2019). The Effects of Consumers' Perceived Values on Intention to Purchase Upcycle Products. Sustainability, 11(4), 1034. https://doi.org/10.3390/su11041034

Zeithaml, V. A. (1988). Consumer perceptions of price, quality, and value: A means-end model and synthesis of evidence. Journal of Marketing, 52(3), 2-22. https://doi.org/10.1177/002224298805200302

Zhang, L., Chen, L., Wu, Z., Zhang, S., \& Song, H. (2018). Investigating Young Consumers' Purchasing Intention of Green Housing in China. Sustainability, 10(4), 1044. https://doi.org/10.3390/su10041044 